\title{
Contributions Of Human Resources Development, Leadership Style, Organizational Commitment, And Work Motivation On Good Governance And Police Officer Performance (Study Of Police Officer In South Sulawesi Regional Police)
}

\author{
Muhammad Dong, Mahfudnurnajamuddin, Baharuddin S. and Baharuddin Latief
}

\begin{abstract}
This purpose of this study was to contribution of human resource development, leadership style, commitment, and motivation on good governance and the performance of members of the Indonesian National Police and the effect of good governance on the performance of members of the Indonesian National Police in the South Sulawesi Regional Police. The study was using 230 police as a sample of a population of 5,069 police in 2019. Data were analyzed using by structural equation modeling with the AMOS assistance version 21. The results showed that (1) human resource development and motivation have a positive and significant effect on good governance and the police officer performance; (2) Leadership style has a negative and significant effect on good governance; (3) Commitment has a negative and insignificant effect on good governance; (4) Leadership style and commitment have a positive and significant effect on the police officer performance; and (6) Good governance has a positive and significant effect on the police officer performance.
\end{abstract}

Index Terms - Human resource development, leadership style, commitment, motivation, good governance police officer performance.

\section{INTRODUCTION}

The reform era brought the Indonesian National Police to meet public expectations, the National Police has made various efforts to reform, organize, strengthen, strengthen, reform towards the Indonesian National Police which is professional and trusted by the community, including setting targets in the implementation of the arrangement and changes, namely for the years 2005-2009, the Indonesian National Police tried to build public trust (building trust), in 2010-2014, the Indonesian National Police built a partnership (partnership building), and in 2015-2025, the

Published on November 16, 2019.

M.D. Author is with the Doctoral Program in Indonesian Muslim University Makassar.

(e-mail: anseplasama9192@gmail.com)

MDJ Author was with Economy and Business Faculty in Indonesian Muslim University Makassar.

(e-mail: mahfudnurnajamuddin@yahoo.co.id)

B.S Author was with Economy and Business Faculty in Indonesian Muslim University Makassar.

(e-mail: ebu279@yahoo.co.id)

B.L Author was with Economy and Business Faculty in Indonesian Muslim University Makassar.

(e-mail: baharlatief@yahoo.com)
Indonesian National Police targeted to achieve excellence (strive for excellence). Based on empirical phenomena which show that the trend of South Sulawesi Regional Police office performance tends to increase this is related to public complaints and the assessment of the Indonesian Police Ombudsman that from 2017 public complaints on performance and services increased by 152 or $(15.2 \%)$, whereas in 2018 increased significantly by 154 or $(15.4 \%)$, and included external police complaints.

This has implications for declining performance through the service of the South Sulawesi regional police office. Due to the fact that there are still members of the Republic of Indonesia Police personnel who abuse their authority, so the public wants the Republic of Indonesia Police personnel in the South Sulawesi Regional Police Station to be more professional in performance and service. The public demanded the quality of service provided by the Indonesian National Police. With excellent service quality, it is hoped that a good perception will be created from the community towards the services provided by the Indonesian National Police. A good perception from the community will foster a sense of satisfaction because it has fulfilled the expectations they want which in turn places trust in the Indonesian National Police. However, public trust in the Republic of Indonesia Police is still low, because the services provided by the Republic of Indonesia Police are not yet excellent or even very poor, therefore research is needed to find out why the quality of the services of the Republic of Indonesia Police is not yet excellent, why the level of public trust is still low and why the reforms that have been carried out by the Indonesian National Police have not reached the target.

This research was developed by referring to several previous studies, which provide evidence that leadership style and organizational commitment have a significant positive effect on the Implementation of Good Governance (Wiratno et al., 2016). Other researchers prove that leadership and human resource development have a significant positive effect on employee performance (Agung Widhi Kurniawan, 2015). Another variable developed in this research model is that there is a significant positive influence between leadership style, work motivation and organizational commitment on employee performance (Fajrina, 2016). These positive and significant results require interesting researchers to be analyzed again in the environment of the Indonesian National Police. 


\section{LITERATURE REVIEW}

\section{A. Human resource development}

The development and empowerment of human resources is a process to improve human knowledge, expertise and skills as well as the abilities of people in society. The difference between training and human resource development lies in the focus of its activities, namely in the focus of training activities is to improve work skills in meeting the demands of the most effective ways of working at the present time. While the focus of human resource development activities is to maintain and enhance the existence of an organization or company in an effort to anticipate future business demands (Hadari Nawawi, 2000: 216; Rachbini, 2001: 123). Training is a short-term educational process for operational employees to gain technical skills operational systematically. The development is a long-term educational process for employees managerial to gain mastery of abstract and theoretical concepts systematically (Tulus, 1992: 88).

The concept of development is broader than education or training (Flippo, 1986: 199-200).development resource Human is an activity that must be implemented by the organization to knowledge (knowledge), abilities (abilities) and skills (skills) they are in accordance with the demands of work (Saydam, 1996: 496). Previous research provides evidence that employee development has a positive and significant effect on employee performance (Abdul Hameed and Aamer Waheed, 2011). Employee development through training has a positive and significant effect on employee performance in the banking industry in Pakistan (Muhammad Imran, 2015). The development of human resources in this study is explained through a process of improving the quality or ability of humans in order to achieve the nation's development goals. This improvement process includes the planning, development and management of human resources. While the development of human resources at a micro level an educational planning process, training, and management of personnel to achieve an optimal result. The indicators are; (1) education, (2) culture training (3), mindset training and (4) career coaching.

\section{Leadership styles}

Leadership styles means one's ability and personality to influence and persuade other parties to take action to achieve common goals, so that by thus concerned becomes the beginning of the structure and center of the group process (Masrukin \& Waridin, 2006). Leadership is an activity to influence the behavior of others so that they want to be directed to achieve certain goals (Miftah, 2001: 67). Leadership is defined as the ability to move or motivate a number of people to simultaneously carry out the same activities and focus on achieving their goals (Nawawi, 2002: 213). Leadership style plays an important role in influencing the performance of employees of government hospitals (Catherine Ruslijanto, 2015). Transformational leadership style is a significant positive predictor of academic staff productivity (Halilu Dahiru Abba, 2016). Leadership style has a significant positive effect on job satisfaction and performance. Leadership style has a significant positive effect on performance through job satisfaction (Ishak Runi, Mansyur Ramli, Syamsu Nujum, Rastina Kalla, 2017). Leadership style in this research is defined as a process to influence in determining organizational goals, motivating followers' behavior to achieve goals, influencing to improve the group and its culture. The indicators are (1) directive leadership style, (2) supportive, (3) participative, and (4) delegative leadership style.

\section{B. Organizational commitment}

Organizational commitment is one of the work attitudes that reflects organizational commitment as a relative strength of the individual in identifying his involvement with a part of the organization that is reflected through his acceptance of values and goals, readiness, and willingness to make a serious effort, and the desire to maintain his involvement in the organization (Mowday et al., 1982; Robbins, 2001) . Based on these explanations, concluding organizational commitment is a psychological state that characterizes the relationship between members and the organization where the individual process occurs to identify themselves with the values, rules, and goals of the organization and make individuals have the desire to maintain their membership and have implications for decisions to proceed its membership in the organization (Meyer \& Allen, 1997; Sjahruddin \& Normijati, 2013).

Empirical evidence shows that commitment has a significant positive effect on job satisfaction and lecturer performance. Commitment has a significant positive effect on lecturer performance through job satisfaction (Sjahruddin \& Sudiro, 2013; Ishak Runi, Mansyur Ramli, Syamsu Nujum, \& Rastina Kalla, 2017). Organizational commitment in this study is mentioned as a psychological state that characterizes the relationship between members and organizations where an individual process occurs to identify themselves with the values, rules, and goals of the organization and make individuals have the desire to maintain their membership. The indicators; (1) affective commitment, (2) normative commitment, (3) continuance commitment, and (4) the similarity of values

\section{Work motivation}

Work motivation is the desire to do something. Motivation is the desire found in an individual who stimulates it to take action or something that is the basis or reason for someone to behave. Motivation can be interpreted as a desire or need that motivates someone to work. The statement explains that motivation is determined by the intensity of his motives. Motivation as a psychological process that drives people to do something. Motivation can originate from within and outside one's self (Rivai, 2004: 36; Usman, 2006: 223).

Theory X and Y from Herzberg (Gibson, Ivancevich \& Donnelly, 2004: 149) explain that there are two factors called factors that make people feel dissatisfied and factors that make people feel or factors that make people feel healthy and factors that motivate people or extrinsic and intrinsic factors. The findings of previous researchers indicate that motivation has a significant relationship with the performance and effectiveness of manufacturing companies, therefore companies must employ and maintain qualifications, employees who are competent and motivated for their success and prosperity (Janes O Samuel, 2017). The most significant motivating factor for job performance is responsibility, while benefits are the second significant factor (Sara Ghaffari, 2017). Work motivation in this study is mentioned as an element that exists within and outside of 
human beings to achieve their expectations by requiring enthusiasm, passion, encouragement or stimulation in acting. The indicators used; (1) desire for achievement, (2) desire for power, (3) affiliation needs, and (4) self-esteem (award) needs.

\section{Good governance}

Good governance is a process that orientates government to the equal distribution of power and authority among all elements of society to influence decisions and policies relating to public life and all efforts to develop their political, economic, social and cultural development in the government system. (Sinambela, 2006: 47). Another scholar's view explains that good governance is something that is difficult to define because it contains ethical meaning. In the sense that something that is considered well in a community, but for other communities may not necessarily get the same assessment (Dwi Payana, 2003: 45). Empirical evidence shows that good governance has a positive and significant effect on the performance of hospital employees (Francis Kyereboah, 2017). Good Governance in this study is a system of good governance in connection with services to the wider community. The indicators are: (1) professional, (2) independent, (3) representative, and (4) democracy.

\section{E. Police officer performance}

Police officer performance is a set of results achieved and refers to the act of achieving and carrying out the work required and the performance is a function of motivation and ability. Another scholar's view states that employee work performance is work related to organizational goals in determining results in quantity, quality, efficient, effective and in accordance with the level of personnel compliance in carrying out structural and functional positions of the entire range of personnel in the organization (Gibson, 2013: 355 ). Performance as a function of interaction between ability and ability (A), motivation or motivation (M) and opportunity or opportunity $(\mathrm{O})$, that is performance $=\mathrm{f}(\mathrm{An} \times \mathrm{M} \times \mathrm{O})$. It means that performance is a function of ability, motivation and opportunity. Thus, performance is determined by factors of ability, motivation and opportunity (Robbins, 2006; Hasanuddin \& Sjahruddin, 2017).

Empirical evidence shows that leadership style (both transformational leadership style and transactional leadership style) has a positive and significant effect on job satisfaction, and job satisfaction has a positive and significant effect on employee performance (Umer Paracha et al., 2012). The performance of police officers in this study is explained as the result of carrying out a job that is carried out with speed, fluency, quality, time and profitable work methods. The indicators are: (1) clean, (2) transparent, (3) accountable, and (4) responsibility.

\section{RESEARCH METHOD}

This research is an explanatory, a research that seeks to find new relationships, and explanatory, namely research carried out by trying explaining the various symptoms that result from an object of research. This research was conducted on 230 members of the National Police at the Sulawesi Regional Police South. Hypothesis testing uses structural equation modeling with analysis moment of structural as a tool. The questionnaire was prepared based on the Interval model with five answer choices with a range of values between 1 and 5 (from strongly disagree to strongly agree).

\section{RESEARCH RESULTS}

\section{A. Respondents}

Respondents in this study were members of the Police at the South Sulawesi Regional Police as many as 230 respondents. Determination of the number of samples using Proportionate stratified random sampling. Characteristics of respondents in the form of gender, age, last education, and years of service, are presented to determine the number of frequencies and percentages of the presence of representative Police Members in providing responses regarding. The following can be seen in a detailed description of the research respondents' data.

\begin{tabular}{|c|c|c|c|}
\hline \multirow[t]{2}{*}{ Characteristics } & \multirow[t]{2}{*}{ Classification } & \multicolumn{2}{|c|}{$\begin{array}{c}\text { Number of } \\
\text { Respondents }\end{array}$} \\
\hline & & $\mathrm{F}$ & $\%$ \\
\hline \multirow{3}{*}{ Gender } & Male & 160 & 69.5 \\
\hline & Women & 70 & 30.4 \\
\hline & $<30$ & 46 & 20.0 \\
\hline \multirow[t]{2}{*}{ Ages } & $31-40$ Years & 139 & 60.4 \\
\hline & $>40$ & 45 & 19.5 \\
\hline \multirow{6}{*}{$\begin{array}{l}\text { Level of } \\
\text { education }\end{array}$} & $\begin{array}{l}\text { High School/ } \\
\text { equivalent }\end{array}$ & 78 & 33.9 \\
\hline & Diploma & 54 & 23.4 \\
\hline & $\mathrm{S} 1$ & 58 & 25.2 \\
\hline & $\mathrm{S} 2$ & 34 & 14.7 \\
\hline & S3 & 6 & 2.60 \\
\hline & Total & 230 & 100.00 \\
\hline
\end{tabular}

The table shows that the frequency of respondents. The highest number of the Police officer at South Sulawesi Regional is male or $160.5 \%$. This shows that the sex of South Sulawesi Police officer is more dominant male, generally respondents have ages 31- 40 years as many as 139 people or $60.4 \%$, age $<30$ years as many as 46 people or $20.0 \%$, while the total age of police members South Sulawesi $>40$ years as many as 45 people or $19.5 \%$. The average member of the South Sulawesi Police has a high school education background or equivalent of 78 people or $33.9 \%$, this means that generally the Police officer at South Sulawesi Regional Police have a high school education background or equivalent Education.

\section{B. Variable description}

TABLE II: RESPONSES TO RESEARCH VARIABLES

\begin{tabular}{lc}
\multicolumn{1}{c}{ Variables } & Mean \\
\hline Human resources development & 4.44 \\
Leadership Style & 4.35 \\
Organizational commitment & 4.33 \\
Work motivation & 4.39 \\
Good Governance & 4.33 \\
Police officer performance & 4.50 \\
\hline
\end{tabular}

Table 2 shows the results of respondents' answers on average obtained a value of 4.44 which means that the respondent's assessment of HR development is quite good, where the indicators of human resource development are 
education, culture trainingset, training mind set, and career coaching. The indicator that gives the highest influence is training culture set where personnel are important for training culture set. However, the lowest contribution is an indicator of career coaching. The results of the description of the Leadership Style variable indicate that the Leadership Style variable indicator shows the average score of the answers of 4.35. This value indicates that the respondent's perception of the Leadership Style gives a pretty good value, which means that indicators of directive style supportive style, participative style, and delegative style, the highest indicator is the delegative style.

Respondents' responses to organizational commitment shows that the Commitment variable indicator has an average answer score of 4.33. This value indicates that the respondents' perception of Commitment is quite good. Likewise, the other indicators partially also show the average score between 4.09 - 4.14, which means that the indicators of affective commitment, normative, continuance and similarity in values are quite good. Simultaneous variable description shows the average answer score of 4.33 . This value indicates that respondents' perceptions of Good Governance provide a pretty good value. Likewise the other indicators also show the average score between 3.77 - 4.20, which means that the Professional, Indicators representative, and democracy are good enough. The highest indicator is Professional. Respondents' responses to the Police officer performance showed that the indicator indicators of the Performance of Police Members simultaneously showed an average score of answers of 4.50 . This value indicates that respondents' perceptions of the performance of the National Police Force gave a pretty good score. Likewise the indicators also show the average score between $3.79-4.11$. This means that the indicators Clean, Transparent, Accountable, Humanist, and Responsibility, are quite good.

\section{Testing of research instruments}

TABLE III: VALIDITY AND RELIABILITY TEST

\begin{tabular}{|c|c|c|c|}
\hline Variables & Indicator & $\begin{array}{c}\text { Pearson } \\
\text { correlation, }\end{array}$ & $\begin{array}{c}\text { Cronbach's } \\
\text { Alpha }\end{array}$ \\
\hline \multirow{5}{*}{$\begin{array}{l}\text { Human } \\
\text { resources } \\
\text { development }\end{array}$} & Education & 0.900 & \multirow{5}{*}{0.971} \\
\hline & Culture & 0,900 & \\
\hline & $\begin{array}{l}\text { Training } \\
\text { Mindset }\end{array}$ & 0.901 & \\
\hline & $\begin{array}{l}\text { Career } \\
\text { Development }\end{array}$ & 0.912 & \\
\hline & Directives & 0.804 & \\
\hline \multirow{4}{*}{$\begin{array}{l}\text { Leadership } \\
\text { style }\end{array}$} & Supportive & 0.804 & \multirow{3}{*}{0.940} \\
\hline & Participatory & 0,753 & \\
\hline & discretionary & 0,795 & \\
\hline & affective & 0.807 & \multirow{5}{*}{0.942} \\
\hline \multirow{4}{*}{$\begin{array}{l}\text { Organizational } \\
\text { commitment }\end{array}$} & Normative & 0.807 & \\
\hline & continuance & 0.785 & \\
\hline & $\begin{array}{l}\text { similarity of } \\
\text { value }\end{array}$ & 0.801 & \\
\hline & Achievement & 0.858 & \\
\hline \multirow{3}{*}{$\begin{array}{l}\text { Work } \\
\text { motivation }\end{array}$} & Power & 0.858 & \multirow{3}{*}{0.955} \\
\hline & Affiliate & 0.662 & \\
\hline & Award & 0.845 & \\
\hline Good & Professionals & 0.776 & 0.940 \\
\hline
\end{tabular}

\begin{tabular}{llll} 
governance & Independent & 0.776 & \\
& Representative & 0.781 & \\
Police officer & Democracy & 0.783 & \\
performance & Transparent & 0.725 & \\
& Accountable & 0.725 & \\
& Humanist & 0.734 & 0.944 \\
& Responsive & 0.767 & \\
\hline
\end{tabular}

Criteria Testing the validity of the value $(r) \geq 0.30$ or $\leq \alpha$ $=0.05$ and the reliability of Cronbach's alpha cut of values based on standardized items $\geq 0.60$ or $(60 \%)$. (Uma Sekaran, 2013).

\section{Assumption of Structural Equation Modeling}

1) Normality Test, the results of the normality test show that the Kolmogorov-Smirnov value of 0.580 with a significant value of 0.697 . Based on these results, the data used in the study were stated to be normally distributed and could be continued for further analysis.

2) Test of Outliers, test outliers data is also called tests outliers of data (extreme)) is the data that appear to have unique characteristics that look very much different from the observations of others, and appears in the form of extreme values is good for a single variable or variables combination (Hair et al., 2010).

3) Outlier test results show that the z-score of each variable is at the threshold of the z-score, in the range of 3 to 4 .

4) Linearity test, Linearity testing data aims to see whether the model used is a linear model. The test results using scatter plot diagrams show the result that the pair of data of all variables shows the tendency of the line of regressions starting from the lower left corner to the upper right. More clearly the linearity test data of this study using scatter plot diagrams. The diagram scatter plot of the linearity test presented shows indicators of paired variables, having a data distribution that follows a pattern linear trend. Based on the results of the test of curve fit and scatter plot, which informs that the pattern of data distribution follows a line linear trend, thus, proving that the data used in this study meets the data linearity requirements.

5) Goodness of fit model.

The feasibility testing of the structural model aims to determine the suitability of the data with the results of observations built and estimated using the value of standardized regression weights. The structural model that is built and estimated consists of direct and indirect relationships referring to the formulation of the problem and research objectives. Structural models are said to be in accordance with observational data if Chi-square is small and non significant at $\alpha=0.05$; probability value $\geq 0.05$; $\mathrm{CMIN} / \mathrm{DF} \leq 2.00 ; \mathrm{RMSEA} \leq 0.80$; and TLI, CFI $\geq$ 0.95 .

TABLE IV: GOODNESS OF FIT

\begin{tabular}{lcc}
\hline Goodness offit & Results & Cut-off \\
\hline Chi-squares & 300,182 & Expected Small \\
Probability & 0.128 & $\geq 0.05$
\end{tabular}




$\begin{array}{lll}\text { RMSEA } & 0.043 & \leq 0.08 \\ \text { GFI } & 0.926 & \geq 0.90 \\ \text { AGFI } & 0.921 & \geq 0.90 \\ \text { TLI } & 0.970 & \geq 0.95 \\ \text { CFI } & 0.991 & \geq 0.95 \\ \text { CMIN / DF } & 1,912 & \leq 2.00\end{array}$

Table 4. Explaining that the significance level (p) of 0.336 indicates that the hypothesis null that there is no difference between the sample covariance matrix and the estimated population covariance matrix is acceptable. With receipt hypothesis null, meaning there is no difference between the sample covariance matrix and the estimated population covariance matrix, so the model is feasible to use. Other indices (CMIN / DF, GFI, AGFI, TLI, CFI, and RMSEA) also indicate the level of acceptance of the model.

\section{E. Confirmatory factor analysis}

Testing the measurement model with Confirmatory Factor Analysis (CFA) in this study aims to assess the indicator variables (observed variables) that define a construct or latent variable that cannot be measured indirectly. Analysis of the indicators used was tested to provide meaning for the label given to the latent variable that was confirmed. Empirical analysis aims to validate the model that has been formed and estimate parameters that are built based on theory and empirical studies.

TABLE V: CONFIRMATORY FACTOR ANALYSIS

\begin{tabular}{|c|c|c|c|}
\hline Indicator & $\begin{array}{l}\text { Loading } \\
\text { Factor }\end{array}$ & $\begin{array}{l}\text { Critical } \\
\text { Ratio }\end{array}$ & $\begin{array}{c}\text { Probability } \\
\text { (p) }\end{array}$ \\
\hline Education & 0,978 & 5,105 & 0,000 \\
\hline $\begin{array}{l}\text { Culture Training } \\
\text { Set }\end{array}$ & 0,932 & 8,611 & 0,000 \\
\hline Mind Training & 0.925 & 4,264 & 0,000 \\
\hline Career Coaching & 1,000 & - & - \\
\hline Directive & 0.969 & 6.706 & 0,000 \\
\hline Supportive & 0.947 & 7.565 & 0,000 \\
\hline Participatory & 0.935 & 6.456 & 0,000 \\
\hline Delegation & 1,000 & - & - \\
\hline affective & 0.913 & 6.023 & 0.000 \\
\hline Normative & 0.990 & 5.173 & 0.000 \\
\hline continuance & 0.944 & 6.701 & 0.000 \\
\hline $\begin{array}{l}\text { The similarity } \\
\text { value }\end{array}$ & 1,000 & - & - \\
\hline Achievement & 0.991 & 5.148 & 0.000 \\
\hline Power & 0.994 & 6.492 & 0.000 \\
\hline Affiliate & 0.894 & 7.528 & 0.000 \\
\hline Award & 1000 & - & - \\
\hline Professionals & 1,000 & - & - \\
\hline Independent & 0.507 & 7.276 & 0.000 \\
\hline Representative & 0.694 & 9.578 & 0.000 \\
\hline Democracy & 0.578 & 7.238 & 0.000 \\
\hline Clean & 1.000 & - & - \\
\hline Transparent & 0.952 & 8.077 & 0.000 \\
\hline Accountable & 0.976 & 7.095 & 0.000 \\
\hline Humanist & 0.930 & 8.774 & 0.000 \\
\hline Responsive & 1,000 & - & - \\
\hline
\end{tabular}

The indicators of human resources development variables consisting of education, culture training set and Mindset Training is as an indicator used to measure HR development variables for members of Police officer of the South Sulawesi. While career guidance is a fixed indicator to measure human resources development variables for Police officer of the South Sulawesi. The indicators of the Leadership Style variable consisting of Directive, Supportive, and Participatory are indicators used to measure the Leadership Style variable on Police officer of the South Sulawesi. While the delegative style is a fixed indicator to measure the Leadership Style variable on Police officer of the South Sulawesi. Indicators of the organizational commitment variable consisting of affective commitments, normative, and continuance commitments are indicators used to measure commitment variables. While the similarity of values is a fixed indicator to measure the commitment variable in Police officer of the South Sulawesi.

The Indicators of motivational variables consisting of achievement needs, power needs and affiliation needs are indicators used to measure commitment variables. While the need for awards are a fixed indicator to measure the work motivation variables of police officers. Indicators of good governance variables consisting of independents, representatives and democracy are indicators used to measure good governance variables. Whereas professional is a fixed indicator to measure good governance variables. Indicators of the performance variables of police officers consisting of transparency, accountability and responsibility are the indicators used to measure the performance variables of police officers. Whereas the net is a fixed indicator to measure good governance variables in Police officer of the South Sulawesi.

\section{F. Effects of human resource development on good governance}

These results have provided information that human resource development contributes to good governance ( $p$ value $=0.030<0.05)$ to realize Good Governance, virtuous and professional resources are needed. Placement of resources as a determinant factor for realizing good governance, because of its position not only as a director, regulator, but also as a controller of organizational resources to achieve goals. Therefore it is necessary to be prepared according to the required qualifications so that they are able to carry out public service tasks more effectively and efficiently. Moreover, along with the implementation of eGovernment, it must be accompanied by professional Police officer. Significant path coefficient between human resource development and good governance explains that human resource development is proven to be able to prove the causal relationship both theoretically and empirically to good governance. In other words, there is a positive and significant relationship between human resource development and good governance.

The National Bureaucracy Reform has been rolled out by the Government in order to improve the performance of State institutions (including the police) towards good governance, clean and free from corruption, collusion and nepotism. (Law Number 2 of 2002 has a State Government Function). The results of this study are in line with the findings of previous researchers, that the development of human resources affects good governance (Wojtczuk, 2015). Human resource development has an influence on Good Governance (Chen et al. (2011). Human resource development carried out in the context of implementing egovernment shows a pretty good indication; this is indicated 
by the increase in employees who have the legality of Bachelor and Masters Education, the legality of training according to their field of work. The agency has not fully met the expected qualifications, but the results achieved can add competent employees. By adding professional competence, employees can reduce the gaps that have been complained of so far. work to support the smooth running of tasks Human resource development carried out through education and training, both through technical training and based training e-government turns out to have a large contribution to support the smooth running of tasks and at the same time can be make it an institutional investment in anticipating workloads and demands from the growing community (Eka Fransiska, 2014).

\section{G. Effect of leadership style on good governance}

The police of bad leadership are the decrease in employee performance in an organization. The results shows that the regression coefficient value is 0.920 and the probability value $(p$-value $=0.021<0.05)$ which means that the leadership style has a negative and significant effect on the performance of police officers. This situation shows that the leadership style applied to the South Sulawesi regional police has not been able to improve the performance of police officers, that any leadership style shown to police members is not good but can increase the professionalism, independence, representation and democracy of the police. The results of this study contradict the results of previous studies that in general people assess the implementation of good governance and leadership style has been assessed as good. That transformational leadership can influence the implementation and implementation of good governance and provide trust to the community (Kesi Widjajanti, 2016). Relevant to the findings of other researchers, that Leadership Style negatively influences Good Governance (Wallach, 2012). There is a strong positive relationship between Leadership Style and Good Governance (Odom et al., 2015). In line with the results of the research and expert opinion above, to be able to create Good Governance, it is important for the South Sulawesi police to create or rebuild more innovative organizational values. These organizational values are then regularly socialized and applied consistently, in order to improve good governance. Good Governance will indirectly encourage the utilization of human resources in a more effective and efficient direction, which in turn will contribute to the creation of national economic growth or development.

\section{H. Effect of organizational commitment on good governance}

Organizational commitment has a negative and not significant effect on Good Governance ( $\mathrm{p}$-value $=0.082>$ 0.05 ). The results of this study can mean that organizational commitment shown by members of the police in the form of commitment affective, normative commitment, continuance commitment, and commitment to equality of value for the organization is still low so that it is unable to improve the good governance of police officers as indicated by the lack of professional, independent, representative, and democracy. The research results reject the findings of previous researchers that commitment has a positive effect on the implementation of good governance (Aprilia Kurniasari, 2017). Organizational commitment has a high impact on the application of good governance principles that are easier to fulfill so that good governance can be achieved (Devi, 2008; Sujana, 2014; Ristanti et al., 2014; Syafrion, 2015; Sari, 2016).

\section{Effect of work motivation on good governance}

The findings in this study indicate that the work motivation has a significant positive effect on good governance $(p$-value $=0.029<0.05)$. That motivation is able to prove the causal relationship both theoretically and empirically to good governance. In other words there is a significant relationship between motivation and good governance. This study is consistent with the findings of previous researchers that motivation has a positive effect on good governance (Nirmala, Rona, 2016). This is also consistent with the opinion of scholars (Maslow, in Robbins, 2006), that humans have a number of needs, one of which is the need for self-fulfillment, the drive to become someone / something according to their ambitions, which includes growth, achievement of potential, and self-fulfillment. The application of good governance requires strong motivation from employees to be able to become public servants, because the main elements of good governance namely accountability, transparency, openness, and the rule of law require hard work from government employees to be able to do it well.

\section{J. Effect of human resources development on Police officer performance}

Human resource development is not only limited to certain tasks, but aims to improve their personalities and attitudes for overall growth that will help them face challenges in the future. This changes the mindset of employees and makes them more challenging or competitive. Significant path coefficient value between the development of human resources and the police officers performance ( $\mathrm{p}$-value $=$ $0.002<0.05$ ). Human Resource Development is the process of preparing individuals to assume higher responsibilities related to increasing intellectual ability to carry out better work. Human resource development leads to learning opportunities that are designed to help workers, which are related to their development. It can be seen from two aspects, namely the quantity that concerns the amount of human resources and the quality that concerns the quality and skills of the police.

This study is consistent with the findings of previous researchers, that improving employee performance, not only in education and training, but also through increasing human resources and other factors, such as: employee safety and welfare, promotion, compensation adjustments in wages, incentives, other benefits, and old age insurance (retirement) that can improve employee performance which is always emphasized on the quality of employees and the quality of training implementation so that they can contribute their thoughts to get maximum work results (M. Arif Nasution, 2014). There is a significant influence between the variables of human resource development on employee performance (Febrisma Ramadhiya Findarti, 2016).

\section{K. Effect of leadership styles on Police officer performance}

The characteristics of leadership are proven to guarantee the existence of an organization, including the attention of subordinates. Therefore one of the requirements that must be 
fulfilled by a leader in a Police agency to encourage the performance level of a Police member is to use a directive and participatory style. The results of the study provide evidence that a significant path coefficient value between the leadership style variables on the police officer performance $(p$-value $=0.021<0.05)$ indicates that the leadership style variable contributes well to improving the police officer performance so that it has an impact on increasing prospects and career development which is in accordance with the wishes and expectations. Indicators on leadership style variables related to careers contribute to this related to career opportunities provided in accordance with expectations, career is closely related to the life demands of a Police officer. Therefore, theoretically the better a person's career eats the better the resulting performance. The police officer performance is greatly influenced by the leadership style, due to the existence of trust in the leadership and colleagues so that the Police provide high integrity. It can be concluded that, the police officer performance of the South Sulawesi still highly uphold the ethics of leadership to be implemented in institutions, so that it has a major impact on the police officer performance.

This research is consistent with the findings of previous researchers, that the leadership style used by leaders is acceptable to employees and will improve performance (Wilson, 1995; Savery, 2001; Lok \& Crawford, 2004; Chew \& Sharma, 2005; Kusumawati, 2008). To improve the performance of police officers through a leadership style approach, that of the three leadership styles analyzed, it turns out that the participative leadership style ranks first in relation to service orientation. This leadership style is measured by the circumstances in which the leader allows subordinates to influence decision making by asking for input or contributions from members (Harris \& Ogbonna, 2016).

\section{Effect of organizational commitment on Police officer performance}

The results of this study prove that organizational commitment has a significant positive effect on the Police officer performance $(\mathrm{p}$-value $=0.018<0.05)$. The results explain that Police officer serving in the South Sulawesi Regional Police try to have commitment in influencing its performance. Commitments made by members of the National Police are shown by always being involved in various organizational activities (affective commitment). This affective commitment is important to produce optimal work results that affect the performance of police officers seen in the field of community service. Police officers are also required to have a normative commitment by showing their contribution in contributing to each activity in achieving organizational goals. This normative commitment becomes a means for every Police Member to be involved in every activity as a manifestation of the actualization of his normative commitment to the South Sulawesi Regional Police. This normative commitment is expected to contribute to the achievement of organizational goals that directly affect the performance of direct involvement in participating in community service according to the mandate given. The findings of this study are consistent with the results of previous studies the relationship between employee commitment to the organization and performance showed significant results (Benkhoff, 2013: 718). There is a positive relationship between commitments to the organization with performance (Brief \& Motowidlo, 2012). Individuals who are committed to the organization are people who are willing to give something of themselves as a contribution to the good of the organization (Mowday, Porter \& Steer, 2009).

\section{Effect of work motivation on Police officer performance}

The findings of this study provide evidence that work motivation has a significant positive effect on Police officer performance $(p$-value $=0.016<0.05)$. Leadership is a process of directing and giving encouragement or motivation. This will influence the activities of a group of members who are interconnected with their duties. Leadership is an important part of management, but it is not the same as management. Leadership is the ability a person has to influence others, who work to achieve goals and objectives. Management includes leadership, but also includes other functions such as planning, organizing, and monitoring. The results of the study are consistent with the findings of previous researchers that work motivation has a positive and significant effect on individual performance (Pridarsanti \& Yuyetta, 2013).

\section{$N$. Effect of good governance on Police officer performance}

The findings of this study provide evidence that there is a significant path coefficient between Good Governance and the Police officer performance $(p$-value $=0.000<0.05)$. This condition shows that good governance is able to prove the causality relationship both theoretically and empirically to the performance of police officers. This condition is caused because the Police officer who understands good governance correctly will affect professional behavior in working with a high-performance orientation to achieve the ultimate goal as expected by various parties. The implementation of good governance is the main prerequisite for realizing the aspirations of the people in achieving the goals and ideals of the nation and state. Good governance is defined as good governance in a business that is based on professional ethics in trying and working. This paradigm requires every member of the Police to be responsible and accountable for all their attitudes, behaviors, and policies to the public in the framework of carrying out what are the main task, function, authority, and responsibility given to him. The findings of this study are consistent with the results of previous studies, that good governance provides a positive and significant effect on the performance of government auditors (Nurwahida et al., 2012; Elyawati et al., 2015; Windiarto, 2015; Madjir, 2015).

O. Effect of human resources development on Police officer performance: As a mediating role of good governance

The results of the calculation of the coefficient of determination of the direct relationship between the human resources development on the Police officer performances amounted to 0.68 , indicating that the performance of Police officer in the South Sulawesi Regional Police can be explained by looking at the total magnitude of influence that is equal to 0.721. By looking at the correlation value (r) which means there is a very strong relationship between human resource development and the Police officers performance. This result is in accordance with the results of 
previous studies showing a strong relationship between human resource development and performance.

Effect of Human Resource Development on the Performance of Police Members through Good Governance can be shown with $\mathrm{p}$-value $=0.016<0.05$. These results indicate that the development of human resources has a significant positive effect on the performance of police officers through good governance. These results explain that one component of good governance is the human resources of the government apparatus; the concept of developing human resources in organizations is defined as power sourced from humans that can be either energy (energy) or strength (power). To improve the quality of resources of members of the Police is not only a matter of changing individuals, but also how to change the system in government organizations (Good Governance), for example the rules of the organization, organizational structure, or can be said to reform in the institutional organization of the government organization first. In addition, members of the Police as a state tool must be able to increase competitiveness, and maintain the integrity of the nation and territory of the country. For this reason, a more comprehensive and integrated effort is needed to encourage the improvement of the performance of police officers in creating a clean and accountable government which is a mandate for reform and people's demands.

\section{P. Effect of leadership style on Police officer performance: As a mediating role of good governance}

The influence of leadership style on the Police officer performance through good governance proved to be significantly positive $(p$-value $=0.021<0.05)$. These results explain that the influence of the Leadership Style on the Performance of Police members is greater if through Good Governance (indirect effect) compared to the direct effect. While the total effect (total effect) of 0.304 which means that the direct or indirect influence between the Leadership Style on the Performance of Police members. The results of this study recommend the importance of efforts to actualize visionary leadership at all levels in the organization by conducting socialization, training, and simulations, debriefing, directing, and exemplary. Actualization of the visionary leadership that consistently will be able to support and promote the paradigm of police Influence Commitment to Performance police members through Good Governance

\section{Q. Effect of organizational commitment on Police officer} performance: As a mediating role of good governance

Effect of organizational commitment to the Police officer performance through good governance was positively significant $(p$-value $=0.005<0.05)$, that in relation to the effectiveness of the organization to achieve high performance, there is a belief that the behavior of members of the Police, especially regarding the commitment of members of the Police, has a great influence on Good Governance and subsequently also affects the Police officer performance. In terms of leadership, high commitment will have an impact on improving performance. This means that the higher the commitment of Police officer in carrying out their duties and responsibilities will contribute positively to the organization.
R. Effect of work motivation on Police officer performance: As a mediating role of good governance

Work motivation as a direct positive and significant effect on the Police officer performance through good governance ( $\mathrm{p}$-value $=0.023<0.05)$. This condition means that high motivation for police officers in carrying out their duties can affect their performance through good governance. Work motivation has a positive and significant effect on the performance of police officers. This shows that the fulfillment of motivation obtained by members of the Police has been in accordance with their expectations. The form of hope desired by members of the Police is high compensation, wants to be respected, conditions of work are conducive, wants to be promoted to have a position, wants to have the authority of responsibility and master the field of work, which directly helps in improving performance. Police members need motivation in improving their performance, even though the compensation given is still below expectations. This compensation motivation helps Police Members to meet their daily needs, and the needs of developing education, research and community service. Therefore requires a budget to buy books, transportation costs, research costs, repair costs and others to always be able to improve its performance. Police officer are motivated by getting improved workplace conditions, which at present many Police officer view the availability of workplace conditions as not representative to develop their performance. Both in the form of procurement of work space and break room and waiting room needed while in the office. The police are one of the government officials who have an obligation to help launch activities in regulating and providing protection to the community. The government issues regulations and one of the objectives is to guarantee legal certainty, create and maintain public order and peace. Police regulations in their implementation require an ability to deal with various violations concerning police order as members of the community apparatus.

\section{S. Limitations of the study}

This research only focused on members of the Police officer in the South Sulawesi Regional Police. The observed variables are only limited to aspects of human resource development, leadership style, organizational commitment, work motivation, good governance, and the Police officer performance which is an important study to determine the level of Police officer performance.

\section{CONCLUSION}

Human Resource Development and work motivation have a positive and significant effect on good governance, while leadership style has a negative and significant effect on good governance and other results indicate that organizational commitment has a negative and not significant effect on good governance Human Resource Development, leadership style, commitment organization, work motivation and good governance have a positive and significant effect on the Police officer performance. In testing the indirect effect, it was shown that Human Resource Development, leadership style, organizational commitment and work motivation had a positive and significant effect on the Police officer performance in the South Sulawesi Regional Police through good governance. Improving the Police officer performance can be done through developing human resources by always 
showing examples of good behavior to the community. Improving a good leadership style can be done by involving members of the Police in various activities. Increased organizational commitment can be done through loyalty to each task and job given. High work motivation can be achieved by providing opportunities for the Police to be promoted in occupying positions, giving authority according to responsibilities and increasing work mastery.

\section{REFERENCES}

[1] Adisty, Hamdani. (2004). Motivation and Organizational Performance. Pustaka Jaya Publisher, Jakarta

[2] Allen, NJ, \& Meyer, JP (1990). The measurement and antecedents of affective, continuance and normative commitment to the organization. Journal of occupational psychology, 63 (1), 1-18.

[3] Bernardin \& Russel. (2012). Organization Management and Performance. Published by Prentice Hall, Ohio Press.

[4] Dessler, Gary. (2007). Human Resources Management, Upper Saddle River, Prentice Hall, New Jersey.

[5] Dessler, Gary. (2011). The Good of Culture Organization in Company. Published by Addison-Wesley Publishing Company.

[6] Furtwengler, Dale. (2004). Performance. Published by Harper T \& Row, New York.

[7] Gimbart, John D. (2008). Behavior Principles in Organization Everyday Life. 2nd ed. Englewood Cliffs, Prentice Hall, New Jersey.

[8] Gomes, Faustino Cardoso. (2011). Human Resource Management, Andi Offset, Yogyakarta.

[9] Hameed, A., \& Waheed, A. (2011). Employee development and its effect on employee performance a conceptual framework. International journal of business and social science, 2 (13).

[10] Hair, J. F., Black, W. C., Babin, B. J., Anderson, R. E., \& Tatham, R. L. (2010). Multivariate data analysi). Upper Saddle River, NJ: Pearson Prentice Hall.

[11] Hasanuddin, R., \& Sjahruddin, H. (2017). The structure of emotional intelligence, spiritual intelligence and its relationship with work enthusiasm and auditor performance. Structure, 3 (1).

[12] Hersey, Paul. (2007). Management for Human Resources. 4th Edition. Englewood Cliffs, New Jersey, Prentice-Hall, Inc.

[13] Imran, M., \& Tanveer, A. (2015). Impact of training \& development on employees' performance in banks of Pakistan. European Journal of Training and Development Studies, 3 (1), 22-44.

[14] Irawan, Hendra. (2011). Management and Performance. Rineka Cipta Publisher, Jakarta.

[15] Ivancevich, Donnelly \& Gibson, JL (2013). Management, Principles and Functions. Fourth Edition, Richard D. Irwin Inc., U SA.

[16] Kadir, Abdul, (2003). Implementation of Training and Development Towards Quality Next Generation. Publisher Raja Grafindo Persada, Jakarta

[17] Kyereboah, F. (2017). Corporate governance and employee performance: A study of St. Dominic Hospital, Akwatia (Doctoral dissertation, University of Cape Coast).

[18] Mangkunegara, AA Anwar Prabu. (2005). Organizational Behavior and Work Performance. PT. Refika Aditama - Bandung

[19] Mathis RL, \& Jackson JH (2002). Human Resource Management, Jakarta: Salemba Empat

[20] Meyer, JP, \& Allen, NJ (1997). Commitments in the workplace: Theory, research, and application. Sage.

[21] Mowday, RT, Porter LW, \& Steers RM (1982). EmployeeOrganization Linkages the Psychology of Commitment absenteeism, and turnover. New York: Academic Press

[22] Nitisemito, Alex. (2009). The HR Paradigm in Work Motivation. Rineka Cipta Publisher, Jakarta.

[23] Paracha, MU, Qamar, A., Mirza, A., Hassan, IU, \& Waqas, H. (2012). Impact of leadership styles (transformational \& transactional leadership) on employee performance \& mediating the role of job satisfaction. Study of private schools (educators) in Pakistan. Global Journal of Management and Business Research, 12 (4), 55-64.

[24] Rivai, Veithzal. (2008). Human Resource Management For Companies. PT.Raja Grafindo Persada, Jakarta.

[25] Robbins, Stephen P. (2006). Organizational Behavior Concepts, Controversies, Applications, 6 Ed. Prentice Hall, Inc. Eaglewood, Cliff, New Jersey

[26] Robbins, Stephen, P., (2009). Motivation Theories. Prentice Hall Int Ed. Englewood Cliffs, New Jersey

[27] Runi, I., Ramli, M., Nujum, S., \& Kalla, R. (2017). Influence Leadership, Motivation, Competence, Commitment To Satisfaction And Performance Lecturer At Private Higher Education Kopertis
Region IX In South Sulawesi Province. Journal of Business and Management (IOSRJBM), 19 (7), 56-67.

[28] Sekaran, Uma. (2013). Research Methods For Business: A Skill Building Approach, John Wiley And Sons Inc., New York,

[29] Simamora, Henry. (2011). Human Resource Management, Second Edition, STIE YKPN, Yogyakarta.

[30] Sjahruddin, H., \& Normijati, AAS (2013). Personality effect on organizational citizenship behavior (OCB): trust in managers and organizational commitment mediators of organizational justice in Makassar City Hospitals (Indonesia). European Journal of Business and Management, 5 (9), 95-104.

[31] Sjahruddin, H., \& Sudiro, AA (2013). Organizational justice, organizational commitment and trust in managers as predictors of organizational citizenship behavior. Interdisciplinary J. of contemporary Res. Bus. (IJCRB), 4 (12), 133-141.

[32] Suhady, Idup. (2005). Good Governance Basics. Jakarta: State Administration Institute.

[33] Wiratno, A., Ningsih, W., \& Putri, NK (2016). Budgetary Participation in Managerial Performance with Organizational Commitment, Motivation and Decentralized Structure as Moderating Variables. Journal of Accounting, 20 (1), 150-16 
